\title{
PROTOTIPE PENGAMAN PINTU RUMAH MENGGUNAKAN VOICE RECOGNITION DENGAN EASYVR BERBASIS MIKROKONTROLER
}

\author{
Syaeful Ulum ${ }^{1}$, Maun Budiyanto ${ }^{2}$ \\ ${ }^{1,2}$ Departemen Teknik Elektro dan Informatika Sekolah Vokasi Universitas Gadjah Mada Yogyakarta \\ ${ }^{1}$ syaeful.ulum@mail.ugm.ac.id, ${ }^{2}$ m.budiyanto@ugm.ac.id
}

\begin{abstract}
The adventages of technology make every job easier, but this ease sometimes isn't matched by safety factors. Security is vital to avoiding this technology being misused by uninvited people.This journal discusses the security of home doors with a microcontroller-based voice. The voice recognition process starts from the sound that propagates and then processes the corresponding easyvr sensor so that the easyvr sends a command to the relay to open the doorlock solenoid. From various tests obtained from voice recognition that can support the sound in the form of recordings, in speech recognition with an achievement level of $45 \mathrm{~dB}$ approved sound with an ideal pitch at 0-700 cm, it needs $75 \mathrm{~dB}$ sound amplifier with an ideal distance of 0-20 cm. For the percentage of success range with $30-40 \%$ different and the percentage of sound success is above $90 \%$.
\end{abstract}

Keywords : voice recognition, easyvr, microcontroller, sound intensity level.

Intisari - Kemajuan teknologi membuat pekerjaan menjadi mudah, namun kemudahan tersebut tidak diimbangi dengan faktor keamanan. Keamanan menjadi hal yang vital untuk menghindari teknologi tersebut tidak disalahgunakan oleh orang yang tidak berwenang. Pada jurnal ini membahas pengaman pintu rumah dengan pengenalan suara berbasis mikrokontroler. Proses pengenalan suara dimulai dari suara yang merambat lalu diproses sensor easyvr jika sesuai sampling maka easyvr mengirimkan perintah kepada relay untuk membuka solenoid doorlock. Dari berbagai pengujian didapatkan bahwa pengenalan suara tidak dapat mengenali suara dalam bentuk rekaman, pada pengenalan suara dengan tingkat kebisingan 45 dB mengenali suara dengan ideal pada jark 0-700 cm, kebisingan $75 \mathrm{~dB}$ mengenali suara dengan ideal pada jarak 0-20 cm. Tingkat persentase keberhasilan suara yang berbeda 30-40\% dan persentase keberhasilan suara yang sama diatas $90 \%$.

Kata kunci : pengenalan suara, easyvr, mikrokontroler, tingkat kebisingan suara.

\section{PENDAHULUAN}

Perkembangan zaman di era industri 4.0 ini menjadikan ilmu pengetahuan dan teknologi mempermudah kehidupan manusia. Seluruh hal yang banyak diterapkan ilmu pengetahuan dan teknologi yang terdiri atas komponen mekanikal dan elektronika, sehingga segala macam pekerjaan manusia bisa dikerjakan dengan waktu yang singkat dan mudah yang mana tidak harus membuang energi. Misalkan pada penggunaan dari teknologi di bidang elektronika yakni pengaplikasian sensor voice recognition digunakan sebagai alat pengaman dan pengatur untuk pembuka maupun penutup pintu rumah otomatis.

Saat ini masih banyak masyarakat masih menggunakan metode pengaman pintu rumah dengan membuka kunci pintu menggunakan kunci dan handle, masalah akan muncul apabila kehilangan atau terlupa kunci tersebut serta dilihat dari sisi keamaan juga apabila terjadi pemindahtanganan kunci kepada orang yang tidak berkepentingan dan bertanggung jawab memilikinya sehingga menimbulkan masalah yang akan lebih besar tentunya. Sistem yang menjamin unsur keamanan, biasanya harus dapat memenuhi unsur biometrik atau behaviour dari penggunanya [1]. Teknologi ini memudahkan dalam menutup atau membuka tanpa susah payah membuka memakai kunci manual. Di lain hal tersebut diperlukan faktor keamanan untuk mencegah akan adanya kegiatan pencurian.

Penelitian sebelumnya oleh [2] membahas mengenai aplikasi voice recognition pada peralatan listrik rumah tangga seperti lampu dan sebagainya, kemudian oleh [3] membahas pula pengaplikasian voice recognition pada kipas yang diintegrasikan dengan Frekuensi Radio. Berdasarkan permasalahan di atas dalam jurnal ini telah dibuat prototipe pengaman pintu rumah, berbasis mikrokontroler menggunakan voice recognition yang dapat menerima input sinyal suara dan disimpan sensor easyvr, easyvr tersebut dihubungkan mikrokontroler yang mengolah dalam bahasa pemograman sehingga melakukan perintah menggerakan doorlock solenoid., cukup dengan mengucapkan "password" yang sebelumnya telah didaftarkan ke dalam sampling data suara modul easyvr 3.0. Perancangan alat ini dapat memenuhi beberapa aspek dalam kebutuhan manusia yakni aspek kemudahan dan keamanan.

\section{PERANCANGAN}

\section{A. Perancangan Sistem}

Dalam merancangan sistem ini, dipilih komponenkomponen yang mudah didapatkan dipasaran. Dipilihnya mikrokontroler sebagai pengendali dikarenakan lebih mudah didapatkan dipasaran, mudah di program, dan sudah dilengkapi dengan port paralel dan port serial sehingga memudahkan dalam berkomunikasi dengan perangkat lain. Diagram blok sistem merupakan diagram dari sebuah sistem yang mempunyai alur proses berupa garis, seperti terlihat pada Gambar 1. Dalam perancangan peralatan, sistem ini dirancang yaitu seseorang mengucap suara melalui microphone kemudian dicocokkan sesuai dengan sampling, jika sesuai maka easyvr menggerakan solenoida untuk mengunci atau membuka.

Fungsi dari setiap komponen dari diagram blok sistem diatas sebagai berikut:

1. Voice gelombang bunyi yang merambat melalui medium udara dengan karakteristik biometric yang berbedatiap manusia.

2. Easyvr sebagai sensor untuk menerima sinyal digitSinyal digital tersebut akan dicocokkan validasi yang masuk dengan karakteristik sinyal 
suara yang ada telah di-samplingsebelumnya. Kemudian apabila cocok maka perintah akan dikirimkan ke mikrokontrolet dimana akan untuk melakukan perintah selanjutnya.

3. Arduino uno sebagai mikrokontroler dimana semua data parameter di diproses yang kemudian mengirimkan perintah ke komponen lainnya

4. Relay sebagai saklar/switch yang mengatur ON OFF berdasarkan dari perintah yang dikirim oleh Arduino uno

5. LCD I2Csebagai penampil informasi perintah kepada pengguna untuk membuka/mengunci pintu

6. Speaker sebagai pemberi informasi dalam bentuk suara atas respon yang telah dilakukan pengguna.

7. Solenoid doorlock sebagai output yang akan mengunci atau membuka sesuai prinip elektromagnetik.

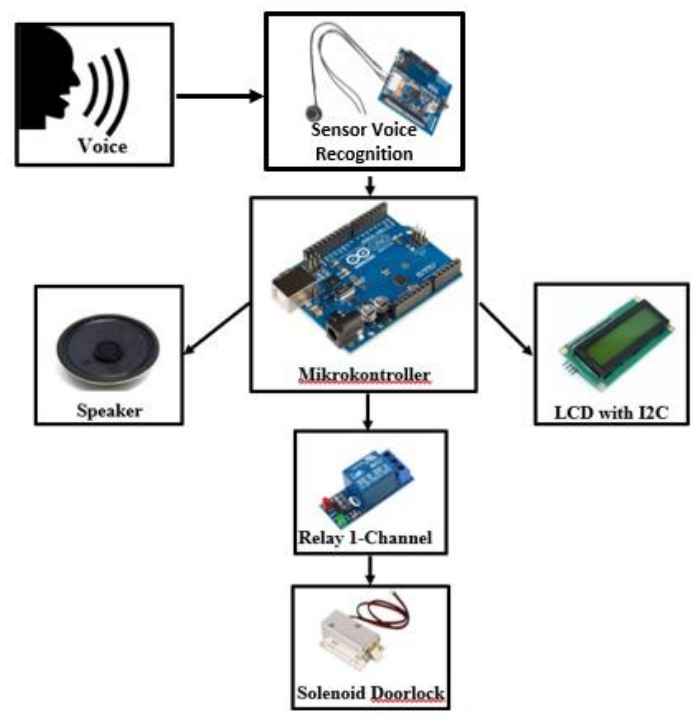

Gambar 1. Diagram blok sistem keseluruhan.

Pada Gambar 2 ditampilkan flowchart cara kerja sistem yang dirancang. Secara ringkas suara diterima oleh microphone lalu dilakukan pengenalan terhadap sampling yang sudah didaftarkan oleh easyvr jika cocok maka relay HIGH sehingga doorlock membuka, begitu pula apabila akan mengunci jika cocok dengan sampling maka relay LOW sehingga doorlock mengunci.

\section{B. Perancangan Elektronis}

Perancangan elektronis terdapat konfigurasi LCD, sensor easyvr dan relay yang diGambarkan pada Gambar 3. Pada konfigurasi arduino dengan easyvr berfungsi saling berkomunikasi data dengan easyvr. Terdiri atasnya adalah TX dan RX dimana pada pin 12 sebagai $\mathrm{RX}$ atau receiver dan pin 13 sebagai TX atau transmitter.

Pada konfiugrasi arduino dengan LCD I2C modul I2C menggunakain IC PCF8574 memiliki pin output dari modul I2C adalah pin SDA, SCL VCC dan GND. Pada pin SDA dihubungkan ke pin A4, pin SCL dihubungkan dihubungkan ke pin A5 dan pin GND I2C ke GND Arduino, pada pin 5V arduino uno dikoneksikan terhadap slot VCC dari I2C. Pada konfigurasi arduino dengan modul relay 1 -channel, modul relay membutuhkan tegangan $5 \mathrm{~V}$ sehingga mampu membuatnya aktif dan sumber daya 5 Volt tersebut dikoneksikan dengan pin
VCC yang telah tersedia di papan arduino. Antara pin GND yang tersedia pada arduino yang disambungkan ground. Kemudian antara pin 5 arduino uno dihubungkan terhadap pin IN. untuk mengontrol solenoiddoorlock yang difungsikan adalah output dari relay normallyopen (NO).

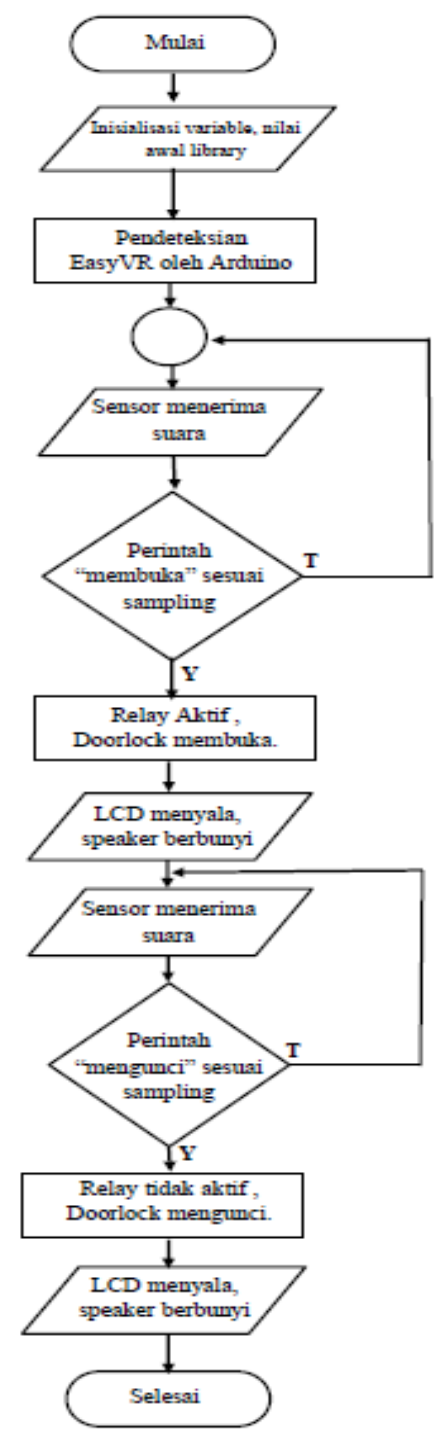

Gambar 2. Flowchart sistem.

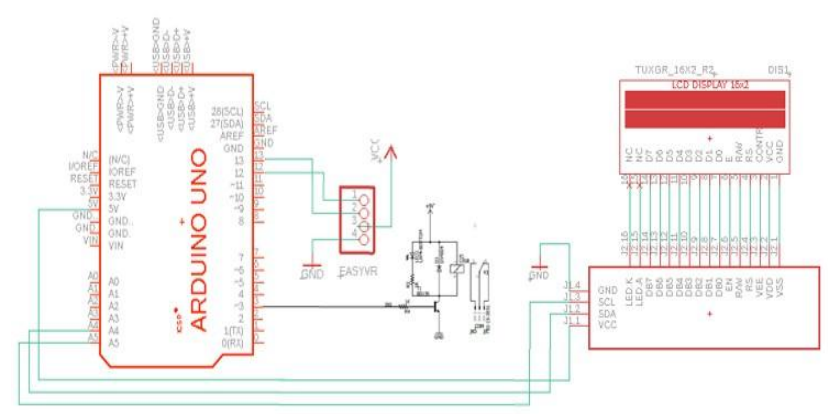

Gambar 3. Perancangan elektronis.

C. Perancangan Mekanis

Dilakukan perancangan dari sisi mekanis pada prototype ini untuk melindungi komponen elektronis yang ada didalamnya, desain mekanis ini menggunakan software solidworks 2018 sehingga memudahkan penulis dalam melakukan perancangan. Pada Gambar 4 diberikan 
perbandingan antara hasil rendering desain solidworks dengan realitas.
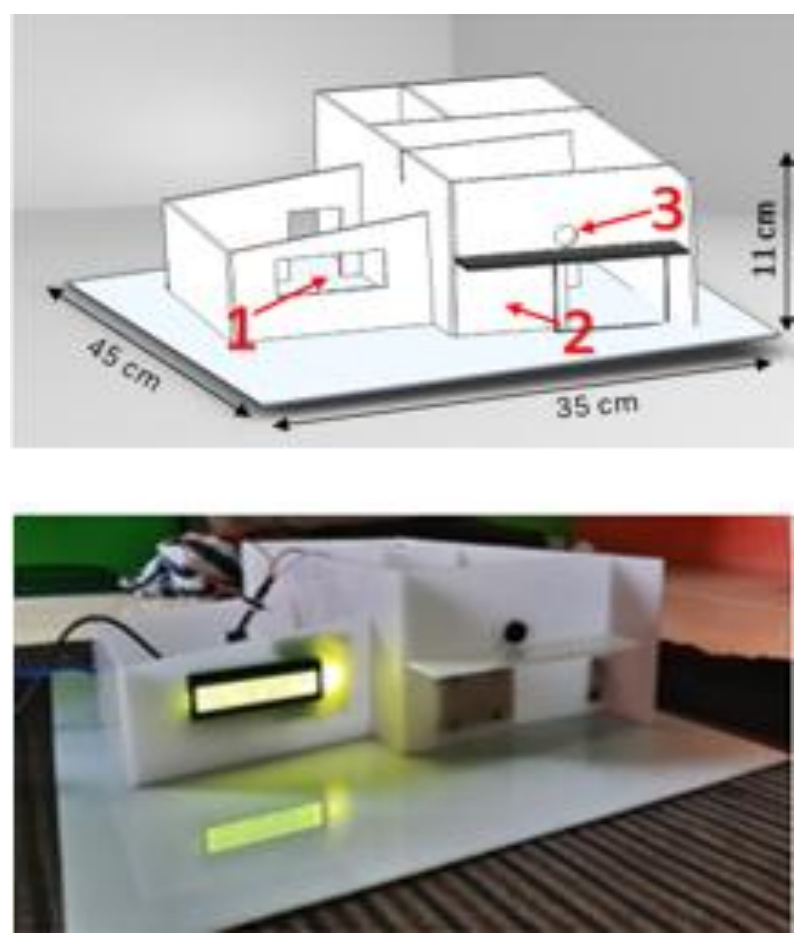

Gambar 4. Perbandingan rendering desain dengan realitas.

Keterangan kode pada di Gambar 4 yaitu:

- Angka 1 adalah tempat peletakan LCD I2C sebagai penampil text

- Angka adalah tempat peletakan solenoid doorlock sebagai pengunci dan pembuka

- Angka 3 adalah tempat peletakan microphone sebagai pemberi perintah suara

\section{HASIL DANPEMBAHASAN}

Dilakukan beberapa macam pengujian alat untuk membuktikan sistem yang sudah diimplementasikan tersebut apakah sudah sesuai dengan sistem yang diharapkan sebelumnya. Macam pengujian antara lain:

\section{A. Pengujian dengan media penghalang}

Suara merambat dari sumber suara menuju tempat lain menggunakan media, media disini codan udara. Pada pengujian ini dilakukan dengan jarak antara suara dengan sensor sebesar $50 \mathrm{~cm}$. Berikut Tabel 1 hasil pengujian dengan media penghalang.

Tabel 1. Hasil pengujian dengan penghalang.

\begin{tabular}{llll}
\hline \multirow{2}{*}{$\begin{array}{l}\text { Jenis } \\
\text { Penghalang }\end{array}$} & \multicolumn{2}{l}{ Pengucapan } & $\begin{array}{l}\text { Persentase } \\
\text { Keberhasilan }\end{array}$ \\
\cline { 2 - 3 } $\begin{array}{l}\text { Bengasil } \\
\text { ventilasi }\end{array}$ & 9 & Gagal & \\
\hline $\begin{array}{l}\text { Tanpa } \\
\text { ventilasi }\end{array}$ & 2 & 8 & $20 \%$ \\
\hline
\end{tabular}

Persentase keberhasilan pada ruangan tanpa ventilasi hanya $20 \%$ dan persentase $90 \%$ pada ruangan dengan ventilasi diperoleh karena kondisi pada ruangan tersebut terdapat ventilasi yang memungkinkan suara dapat merambat melewati ventilasi menuju sensor easyvr.

B. Pengujian dengan file rekaman suara

Pengujian ini menggunakan suara rekaman 2 orang yang berbeda, yang dimasukkan dalam sampling. Pengujian ini dilakukan sebanyak 10 kali.

C. Pengujian dengan Suara orang 1

1) Pengaruh jarak terhadap pengenalan suara.pada tingkat kebisingan $45 \mathrm{~dB}$

Pengujian ini menggunakan parameter jarak dan tingkat kebisingan sebesar $45 \mathrm{~dB}$. Pengujian ini dilakukan di rumah dan dilakukan beberapa kali pengujian dengan jarak pada pengguna yang yang sama. Hasil pengujian terlihat Tabel 3.

Tabel 3. Hasil validasi suara terhdap jarak dengan $45 \mathrm{~dB}$

\begin{tabular}{ccccccc}
\hline Indikator & \multicolumn{7}{c}{ Jarak (m) } \\
\cline { 2 - 7 } & 1 & 3 & 5 & 7 & 9 & 12 \\
\hline $\begin{array}{c}\text { Keberhasilan } \\
\text { dari 10 kali } \\
\text { percobaan }\end{array}$ & 10 & 9 & 9 & 7 & 4 & 2 \\
\hline$\%$ Keberhasilan & $100 \%$ & $90 \%$ & $90 \%$ & $70 \%$ & $40 \%$ & $20 \%$ \\
\hline
\end{tabular}

Berdasarkan Tabel 5 di atas dapat diperlihatkan bahwa kemampuan kinerja deteksi jarak terjauh sensor suara adalah $12 \mathrm{~m}$. Namun, kinerja optimal dari sensor easyvr ini adalah dengan jarak 0-7 m yang memiliki tingkat persentase keberhasilan diatas $70 \%$, sehingga pengenalan suara dengan sensor easyvr dapat bekerja secara optimal dan akurat.

\section{2) Pengaruh jarak terhadap pengenalan suara.pada tingkat kebisingan $75 \mathrm{~dB}$}

Pengujian ini menggunakan parameter jarak dan tingkat kebisingan sebesar $75 \mathrm{~dB}$. Hasil pengujian terlihat pada Tabel 4.

Tabel 4. Hasil validasi suara terhadap jarak dengan $75 \mathrm{~dB}$

\begin{tabular}{|c|c|c|c|c|c|}
\hline \multirow{2}{*}{ Indikator } & \multicolumn{5}{|c|}{ Jarak (cm) } \\
\hline & 10 & 20 & 30 & 40 & 50 \\
\hline \multicolumn{6}{|l|}{ Keberhasilan dari } \\
\hline 10 percobaan & 8 & 7 & 5 & 2 & 0 \\
\hline \%Keberhasilan & $80 \%$ & $70 \%$ & $50 \%$ & $20 \%$ & $0 \%$ \\
\hline
\end{tabular}

Berdasarkan Tabel 4 diatas dapat dinyatakan bahwa kemampuan kinerja deteksi jarak terjauh sensor suara sebesar $40 \mathrm{~cm}$. Kinerja optimal sensor dengan jarak sebesar 0-20 cm, karena memiliki persentase keberhasilan diatas $70 \%$.

D. Pengujian dengan suara orang yang berbeda

Pengujian kali ini bertujuan untuk mengetahui persentase keberhasilan sensor easyvr dalam memproses perintah suara orang yang berbeda. Tabel 5 memperlihatkan hasil pengujian suara dari orang yang berbeda. 
Tabel 5. Hasil pengujian siara orang yang berbeda

\begin{tabular}{ccccc}
\hline \multirow{2}{*}{ Indikator } & \multicolumn{5}{c}{ Pengucap } \\
\cline { 2 - 5 } & Orang 1 & Orang 2 & Orang 3 & Orang 4 \\
\hline $\begin{array}{c}\text { Keberhasilan } \\
\text { dari 10 } \\
\text { percobaan }\end{array}$ & 3 & 6 & 4 & 1 \\
\hline \% Keberhasilan & $30 \%$ & $60 \%$ & $40 \%$ & $10 \%$ \\
\hline
\end{tabular}

Berdasarkan Tabel 5, pada orang ke-4 berjenis kelamin perempuan. Intonasi suara yang dihasilkan berbeda dengan sampling sehingga tingkat keberhasilan $10 \%$. Pada orang ke-1 dan ke-3 terdapat 3-4 kali intonasi yang mirip terhadap intonasi suara sampling sehingga persentase keberhasilan mencapai $30-40 \%$. Pada orang ke-2 memiliki persentase keberhasilan yang cukup tinggi yakni $60 \%$ dikarenakan orang tersebut mengetahui nada intonasi dari sampling yang diucapkan.

\section{E. Pengujian Suara dengan Menggunakan Pengeras}

\section{Suara}

Pengujian ini bertujuan untuk mentahui keberhasilan dari variasi tingkat volume speaker terhadap pengenalan sensor easyvr. Tabel 6 memperlihatkan hasil pengujian pada pengeras suara.

Tabel 6. Hasil pengujian terhadap tingkat volume

\begin{tabular}{ccc}
\hline \multirow{2}{*}{ Indikator } & \multicolumn{2}{c}{ Tingkat Volume Speaker } \\
\cline { 2 - 3 } & Volume 25\% & Volume 50\% \\
\hline $\begin{array}{c}\text { Keberhasilan dari 10 } \\
\text { percobaan }\end{array}$ & 7 & 7 \\
\hline \% Keberhasilan & $70 \%$ & $70 \%$ \\
\hline
\end{tabular}

Berdasarkan pada Tabel 6, divariasikan level volume sehingga tingkat keberhasilan sebesar $70 \%$. Hal ini terjadi karena suara tersebut dikeraskan maka sinyal analog tersebut hanya diperkeras, namun tidak merubah dari karakteristik gelombang yang dihasilkan.

\section{KESIMPULAN}

Pada tingkat kebisingan $45 \mathrm{~dB}$ jarak ideal 0-700 cm, sedangkan tingkat kebisingan $75 \mathrm{~dB}$ jarak ideal $0-20 \mathrm{~cm}$. Tingkat presentase keberhasilan suara yang sama 30$40 \%$, dan suara personal diatas $90 \%$. Penggunaan jumlah kata perintah mempengaruhi terhadap pengenalan suara, dan menentukan kecepatan kerja sistem membuka atau menutup pintu.

\section{DAFTAR PUSTAKA}

[1] Prabhakar, S., Pankanti, S., \& Jain, A. K. (2003). Biometric recognition: Security and privacy concerns. IEEE Security and Privacy, 1(2), 33-42. https://doi.org/10.1109/MSECP.2003.1193209

[2] Saputri, Z. N. (2014). Aplikasi Pengenalan Suara Sebagai Pengendali Peralatan Listrik Berbasis Arduino Uno. Aplikasi Pengenalan Suara Sebagai Pengendali Peralatan Listrik Berbasis ArduinoUno, 1(1), 8 .
[3] Hasan, N. F., Rejab, M. R. M., \& Sapar, N. H. (2015). Implementation of speech recognition home control system using Arduino. ARPN Journal of Engineering and Applied Sciences, 10(23), 1749217. 